\title{
EVALUATION OF TEMPERATURE CHANGES IN ANAEROBIC DIGESTION PROCESS
}

\section{Senem Önen Cinar * and Kerstin Kuchta}

Institute of Environmental Technology and Energy Economics, Hamburg University of Technology, Harburger Schlossstr. 36, 21079 Hamburg, Germany

Article Info:

Received:

15 July 2019

Revised:

5 December 2019

Accepted:

21 January 2020

Available online:

5 March 2020

Keywords:

Anaerobic digestion

Temperature effect

Temperature adaptation

Optimization

\section{ABSTRACT}

The study examines the effect of temperature fluctuations on biogas production efficiency in biogas plants with the aim of evaluating the temperature flexibility of the process. Laboratory scale batch reactors were prepared with the chosen substrate (Dried Distillers Grains with Soluble, DDDS) and the study was conducted in three batches. A biogas formation potential test was implemented in each batch in a temperature-controlled room and in a temperature controlled water bath. The temperature changes took place on the third day of tests to evaluate the effect of $5^{\circ} \mathrm{C}$, $10^{\circ} \mathrm{C}$ and $15^{\circ} \mathrm{C}$ increases on biogas production efficiency in separate test sets. Batch experiments showed that it is possible to ensure process recovery after $5^{\circ} \mathrm{C}$ and $10^{\circ} \mathrm{C}$ increases. Overall, the specific biomethane production was obtained between $364-412 \mathrm{Nml} \mathrm{CH}_{4} / \mathrm{g}$ oDM. Unlike $5^{\circ} \mathrm{C}$ and $10^{\circ} \mathrm{C}$ increases, after $15^{\circ} \mathrm{C}$ increase a lower methane content was obtained. These results show that it is possible to have flexible temperature operation in the process, even with high-temperature increases.

\section{INTRODUCTION}

Anaerobic digestion is a microbiological process which supplies energy production and evaluation of organic waste as a resource. Moreover, upgraded biogas is used as a vehicle fuel, and it is possible to inject in natural gas grids. Although it is a beneficial process in various ways, further development is necessary for this process in order to reduce energy consumption and improve process stability (J.B. Holm-Nielsen, 2009) (Ye Chen, 2007). Within the four successive stages (hydrolysis, acidogenesis, acetogenesis, and methanogenesis) of anaerobic digestion, organic material is converted into gas mixture in the absence of oxygen (FNR, 2010). Although the steady operation is possible in a single environment, there are different kinds of active microorganisms in each stage. Other parameters to supply stability of the process are continuous and consistent feeding, a stable temperature, constant stirring, and continuous monitoring (FNR, 2010) (Drosg, 2013).

The active microorganisms in the process of anaerobic digestion are divided into three temperature ranges due to their optimal growth rate temperatures: psychrophilic $\left(<25^{\circ} \mathrm{C}\right)$, mesophilic $\left(37^{\circ} \mathrm{C}-42^{\circ} \mathrm{C}\right)$ and thermophilic $\left(>50^{\circ} \mathrm{C}\right)$ (FNR, Biogas, 2013). Concerning the temperature, the dependence of both enzymatic reactions, and microorganisms ' growth rates, temperature effect on reaction kinetics in the process cannot be neglected (Gerardi M. H., 2003). There are various studies that compare the efficiency of thermophilic and mesophilic anaerobic digestion which show that thermophilic digestion is a better option to digest easily degradable substrates in a short time (Streitwieser, 2017) (Demirel Burak, 2008) (Moset Veronica, 2015). According to Zhang, a higher methane yield and volatile solid removal efficiency can be obtained in thermophilic conditions as compared to mesophilic conditions from soybean curd residue (Le Zhang, 2019). After incubation of the maize silage and cattle manure at $20^{\circ} \mathrm{C}, 30^{\circ} \mathrm{C}$ and $40^{\circ} \mathrm{C}$, higher biogas generation was observed at higher temperatures (Dominika Kufka, 2019). Although higher biogas production can be observed at higher temperatures, however, the mesophilic temperature range is preferable due to its stability and low energy consumption (Rafaela Franqueto, 2019). Furthermore, the effect of one-step and stepwise temperature changes on biogas production has also been studied in various ways to see the adaptation of the process after readjustment to initial operation temperatures (Wu Man-chang, 2006) (El-Mashad Hamed M., 2004) (Iranpour R., 2002).

According to other studies, the temperature shocks and fluctuations in the biogas plant are to be avoided (FNR, 2010) (El-Mashad Hamed M., 2004). Thermal shocks are more effective on system stability at higher temperatures $\left(>55^{\circ} \mathrm{C}\right)$ than at lower temperatures (K. Kundu, 2014). Sim- 
ilarly, the process is more sensitive to temperature changes within $15-20^{\circ} \mathrm{C}$ as compared to the range within 20 $35^{\circ} \mathrm{C}$ (Deng, 2014). On the other hand, in some situations, temperature fluctuations cannot be prevented. Recently, a study by Matteo examined the overheating problem of small-scale digesters in summer with different gasometer dome materials. It showed that the temperature in the biogas reactor can reach $45^{\circ} \mathrm{C}$ due to the overheating problems (Matteo Bavutti, 2014). Since biogas plants generally do not have cooling systems, it is possible to have higher temperatures than expected inside the reactors because of increasing summer temperatures outside. Therefore, extra heat energy gained from high ambient temperatures or solar radiation can be considered an energy source which can enable the operation of biogas plants without heating.

The purpose of this study was to examine the temperature flexibility of the process in case of overheating problems or the operation of the plant using ambient heat in the summer season. A biogas formation potential test was implemented to the chosen substrate in order to evaluate the effect of temperature changes on biogas formation efficiency. Furthermore, the biogas formation efficiency of changing temperature conditions was compared to stable temperature conditions for each batch of the experiment.

\subsection{Highlights}

- Increasing ambient temperature in summer causes temperature management problems in biogas plants;

- Obtaining temperature flexibility in an anaerobic digestion process can give an opportunity to decrease the energy requirement of the plant;

- $5^{\circ} \mathrm{C}, 10^{\circ} \mathrm{C}$ and $15^{\circ} \mathrm{C}$ temperature increases were evaluated with biogas formation potential tests in the laboratory;

- Adaptation of an anaerobic digestion process to $5^{\circ} \mathrm{C}$ and $10^{\circ} \mathrm{C}$ temperature increases were achievable.

\section{MATERIALS AND METHODS}

\subsection{Feedstock and preparation}

DDGS-Pellets were supplied by Crop Energies AG. They are mainly used as concentrated feed material for animals. Studied substrate contains $327 \mathrm{~g} / \mathrm{kg}$ DM (dry matter) crude protein, $79 \mathrm{~g} / \mathrm{kg}$ DM crude fiber, $77 \mathrm{~g} / \mathrm{kg}$ DM crude lipids, $78 \mathrm{~g} / \mathrm{kg}$ DM starch sugar, $455 \mathrm{mg} / \mathrm{g}$ DM TOC (total organic carbon), $13184 \mathrm{mg} / \mathrm{l}(1 \mathrm{~g}$ in $100 \mathrm{ml}$ distilled water dissolved) COD (chemical oxygen demand), $49.69 \mathrm{mg} / \mathrm{g}$ DM TKN (total Kjeldahl nitrogen), $136 \mathrm{mg} / \mathrm{l}(1 \mathrm{~g}$ in $100 \mathrm{ml}$ distilled water dissolved) $\mathrm{NH}_{4}-\mathrm{N}, 24 \mathrm{mg} / \mathrm{l}(1 \mathrm{~g}$ in $100 \mathrm{ml}$ distilled water dissolved) $\mathrm{HCO}_{3}^{-}$and $62 \mathrm{~g} / \mathrm{kg}$ DM crude ash. The feed material described is produced from wheat, barley, molasses, triticale, and corn (Protigrain, 2019). Implemented analytical methods for feedstock/digestate sample analyses are summarized in Table 1. The feed material is stored at room temperature in a plastic container until the experiment is conducted. The pellets were reduced in size before being mixed with inoculum. The inoculum was obtained from waste water treatment plant in Hamburg and was stored in an air-conditioned room $\left(36^{\circ} \mathrm{C} \pm 0.5\right)$ before the tests.

For each batch, blank, reference, and substrate-inoculum mixtures were prepared in three parallels, according to VDI 4630 (VDI, 2014). Reference-inoculum (substrate: cellulose) and pellets-inoculum mixtures were prepared obtaining the oDM (organic dry matter) ratio between substrate and inoculum as given in Equation 1.

$\frac{\text { oDM substrate }}{\text { oDM inoculum }} \leq 0.5$

Where is organic dry matter mass of substrate $(\mathrm{g})$, and oDM inoculum is organic dry matter mass of inoculum (g) (VDI, 2014).

\subsection{Experimental setup and procedures}

The experimental part of this study includes three batches of biogas formation potential tests. For each batch, biogas formation potential of pellets was analysed with different temperature increases $\left(5^{\circ} \mathrm{C}, 10^{\circ} \mathrm{C}\right.$ and $\left.15^{\circ} \mathrm{C}\right)$. Considering the biogas formation quality difference of inoculum, the analyses at $36^{\circ} \mathrm{C}$ were repeated for each batch in order to have a reference for the comparison of the situation with stable temperature management. The biogas formation potential of samples was determined according to German standard procedure (VDI, 2014) as a batch test in three parallels. The lab-scale $500 \mathrm{~mL}$ glass reactors were used with a gastight apparatus and eudiometer, as described in Figure 1. After the implementation of size reduction to the substrate, substrate-inoculum mixtures were prepared as mentioned in Equation 1.

The three batches of experiments were all started at $36^{\circ} \mathrm{C}$. On the thirdday, temperature increases of $5^{\circ} \mathrm{C}, 10^{\circ} \mathrm{C}$ and $15^{\circ} \mathrm{C}$ occurred, as explained in Figure 1. All experiments were conducted in a temperature-controlled room at $36 \pm 0.5^{\circ} \mathrm{C}$. In order to increase the temperature of the reactors, a thermostatic water bath was used continuously from the third day of the experiment onwards. The water level in the water bath was constantly kept higher than the fill levels in the reactors. To supply homogeneity inside the reactors and prevent precipitation, daily shaking was implemented.

At the beginning of the test, the produced biogas quantity was recorded daily, later two to three- days every week. The temperature of the room and water bath and the pressure were recorded daily. The test duration for all experiments was a minimum of 21 days, depending on the biogas generation amount (less than $0.5 \%$ of the total volume that was produced up to that time) on the last days of the test.

The specific fermentation gas production was calculated as explained in the following equations.

$V_{t r, N}=\mathrm{V} \cdot \frac{\left(\mathrm{p}-p_{w}\right) \cdot T_{N}}{p_{N} \cdot \mathrm{T}}$

Where $\mathrm{V}_{\mathrm{tr}, \mathrm{N}}$ is the volume of dry gas in the normal state $\left(\mathrm{ml}_{\mathrm{N}}\right), \mathrm{V}$ is the volume of the gas as read off $(\mathrm{ml}), \mathrm{p}$ is the pressure of the gas phase at the time of reading $(\mathrm{hPa}), \mathrm{p}_{\mathrm{w}}$ is the vapor pressure of the water as a function of the temperature of ambient space ( $\mathrm{hPa}), \mathrm{T}_{\mathrm{N}}$ is the normal temperature $\left(273^{\circ} \mathrm{K}\right), \mathrm{p}_{\mathrm{N}}$ is the normal pressure $(1013 \mathrm{hPa})$, and $\mathrm{T}$ 
TABLE 1: Conducted analytical analyses for the substrate and inoculum.

\begin{tabular}{|c|c|c|c|}
\hline Parameter & Method & Equipment & Standard/ Norm \\
\hline Dry matter content (DM) & Drying at $105^{\circ} \mathrm{C}$ during 24 hours & Drying oven & DIN 38414 - S2 (DIN, 1985) \\
\hline Organic Dry Matter Content (oDM) & $\begin{array}{l}\text { Dried samples from DM test were } \\
\text { treated in muffle furnace at } 220^{\circ} \mathrm{C} \\
\text { within } 20 \text { minutes, at } 300^{\circ} \mathrm{C} \text { within } \\
30 \text { minutes and at } 550^{\circ} \mathrm{C} \text { oven } 5 \\
\text { hours }\end{array}$ & Oven & DIN 38409- H1- 3 (DIN, 1987) \\
\hline Total organic carbon (TOC) & $\begin{array}{l}\text { Thermal oxidation of organic car- } \\
\text { bon to } \mathrm{CO}_{2} \text {, infrared spectroscopic } \\
\text { measurement of } \mathrm{CO}_{2} \text { (TC) } \\
\text { Expulsion of inorganic carbon } \\
\text { (TIC) as } \mathrm{CO}_{2} \text { with phosphoric acid, } \\
\text { quantification of } \mathrm{CO}_{2} \text { via infrared } \\
\text { spectroscopy }\end{array}$ & Analyser multi N/C 2000 & DIN EN 1484 (DIN, 2019) \\
\hline Chemical oxygen demand (COD) & $\begin{array}{l}\text { Oxidation with potassium } \\
\text { di-chromate in \% weight of silver } \\
\text { sulphate (catalyst), photometric } \\
\text { determination of excess potassium } \\
\text { dichromate }\end{array}$ & $\begin{array}{l}\text { Digestion block; HT } 200 \\
\text { Photometer; DR } 3900\end{array}$ & ISO 15705 (ISO, 2002) \\
\hline Total Kjeldahl nitrogen (TKN) & $\begin{array}{l}\text { Transfer of the organically bounded } \\
\text { nitrogen compounds, ammonium, } \\
\text { nitrate and nitrite by digesting the } \\
\text { sample with Kjeldahl tablets } \\
\text { Distillation of the ammonia formed } \\
\text { after the addition of strong liquor } \\
\text { in a template of hydrochloric acid } \\
\text { and determination of analytical end } \\
\text { point }\end{array}$ & $\begin{array}{l}\text { Digestion block, distillation appara- } \\
\text { tus; vapodest } 2 \text { semiautomatic } \\
\text { Titration programme; Schott }\end{array}$ & A 2.2.1 (Methodenbuch) \\
\hline $\begin{array}{l}\text { Ammonium } \\
\left(\mathrm{NH}_{4}-\mathrm{N}\right)\end{array}$ & $\begin{array}{l}\text { Ammonium nitrogen is distilled off } \\
\text { from the weakly basic solution as } \\
\text { ammonia }\left(\mathrm{NH}_{3}\right) \text {, collected in boric } \\
\text { acid solution and determined by } \\
\text { measurement }\end{array}$ & $\begin{array}{l}\text { Distillation apparatus: Vapodest } 2 \\
\text { semiautomatic } \\
\text { Titration programme; Schott }\end{array}$ & DIN 38406-E5-2 (DIN, 1983) \\
\hline $\begin{array}{l}\text { Hydrocarbonate } \\
\left(\mathrm{HCO}_{3}^{-}\right)\end{array}$ & $\begin{array}{l}\text { Titration with } 0.1 \mathrm{~N} \text { hydrochloric } \\
\text { acid solution to } \mathrm{pH} 4.3\end{array}$ & $\begin{array}{l}\text { Titration unit consisting of the com- } \\
\text { ponents T100, TA10, TM120 }\end{array}$ & DIN 38409-7 (H7) (DIN) \\
\hline
\end{tabular}

is the temperature of the fermentation gas of the ambient space $\left({ }^{\circ} \mathrm{K}\right)(\mathrm{VDI}, 2014)$.

$V_{S}=\frac{\sum V_{n} \cdot 10^{4}}{m \cdot D M . o D M}$

Where $\mathrm{V}_{\mathrm{s}}$ is the specific fermentation gas production relative to organic dry mass during the test period $\left(\mathrm{I}_{\mathrm{N}} / \mathrm{kg}\right.$ $\mathrm{oDM}$ ), is the net gas volume of the substrate during the test period $\left(\mathrm{ml}_{\mathrm{N}}\right), \mathrm{m}$ is the mass of the weighted substrate or reference substrate $(\mathrm{g}), \mathrm{DM}$ is the dry matter content of the inoculum or substrate (\%), oDM is the loss on ignition of the sample or inoculum (\%) (VDI, 2014).

The volume fractions of methane and carbon dioxide were determined to depend on the regular intervals with Gas Chromatography (HP 6890 Agilent) with the help of a thermal conductivity detector. Moisture correction for gas components was conducted as in Equation 4, since all biogas content measurements were conducted with water vapor containing biogas.

$C_{\text {tr }, \text { korr }}=C_{\mathrm{CH} 4(\mathrm{CO} 2)} \frac{100}{C_{\mathrm{CH} 4}+C_{\mathrm{CO} 2}}$

Where $\mathrm{C}_{\mathrm{t}, \mathrm{korr}}$ is corrected concentration of the biogas components in dry gas (\%), $\mathrm{C}_{\mathrm{CH}_{4}(\mathrm{CO} 2)}$ is measured concentration of biogas components in the gas (\%), $\mathrm{C}_{\mathrm{CH} 4}$ is measured methane concentration in the gas (\%), $\mathrm{C}_{\mathrm{CO} 2}$ is measured carbon dioxide concentration in the gas (\%) (VDI, 2014).

\section{RESULTS AND DISCUSSION}

\subsection{Results of DM and oDM Analyses}

Table 2 presents the results of DM and oDM content analyses of inoculum and pellets. Moreover, DM and oDM contents of cellulose are presented in Table 2 as well. Because the used inoculum samples were taken from the wastewater treatment plant at different times, DM and oDM contents of inoculum were analysed for each batch. The oDM content of inoculum varied between $62.3 \%$ and $64.4 \%$; that shows the suitability of inoculum for the test, according to VDI 4630 (VDI, 2014).

\subsection{Biogas Generation}

The batches were entitled as $\mathrm{A}\left(5^{\circ} \mathrm{C}\right.$ increase), $\mathrm{B}\left(10^{\circ} \mathrm{C}\right.$ increase), and $C\left(15^{\circ} \mathrm{C}\right.$ increase), and the results will now be presented with those classifications. With all batches, the test continued until no significant amount of biogas production was observed anymore. The temperature- increased cases were compared to the stable temperature operation cases for each batch.

In batch A,there was no significant difference between the specific biogas production amounts of the substrate at $36^{\circ} \mathrm{C}(600.20 \pm 23.34 \mathrm{Nml} / \mathrm{g} \mathrm{oDM})$ and at $41^{\circ} \mathrm{C}$ $(591.37 \pm 23.34 \mathrm{Nml} / \mathrm{g}$ oDM$)$, because the operating temperature was kept in the mesophilic temperature range. As shown in Figure 2, similar cumulative specific fermentation gas production curves were obtained. Compared 


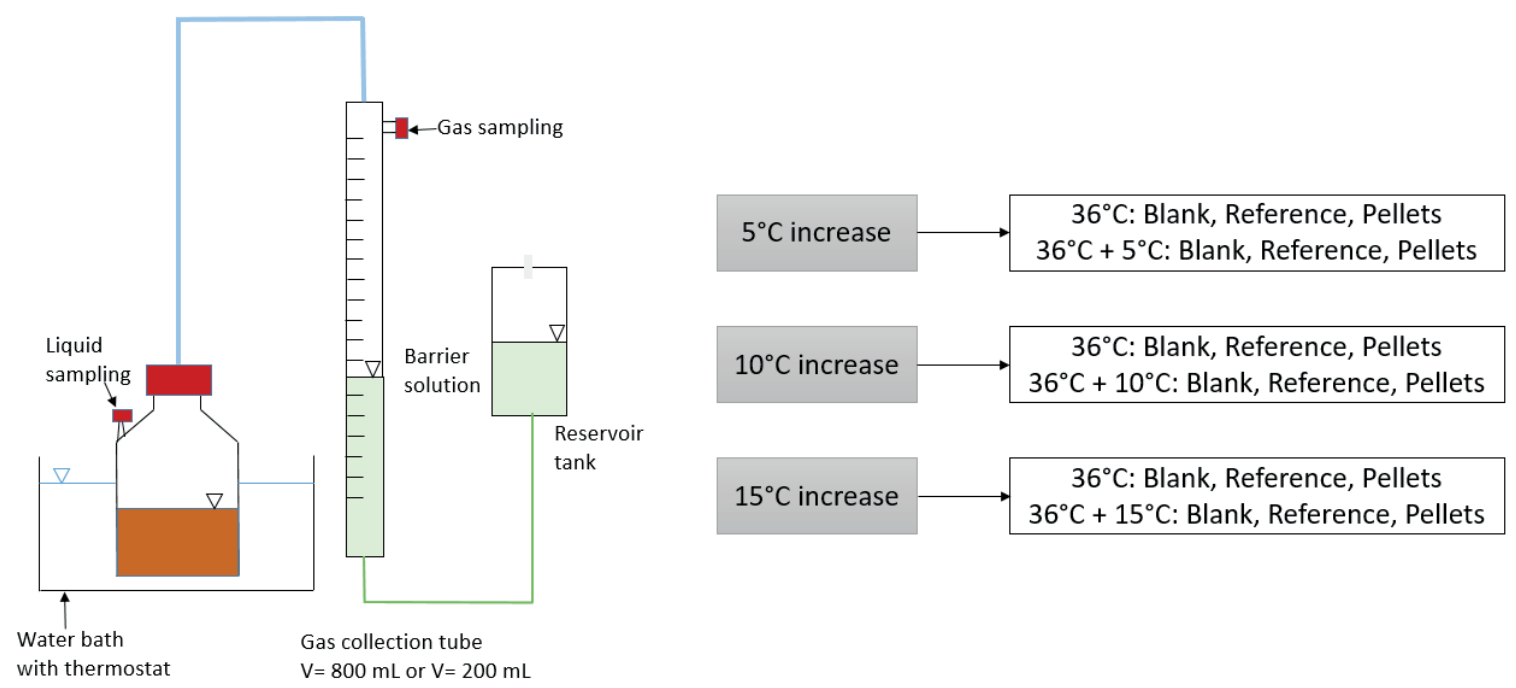

FIGURE 1: Experimental set-up for determination of biogas formation potential and experimental plan.

to the temperature-increased test, at $36^{\circ} \mathrm{C}, 42 \mathrm{Nml}$ higher biomethane generation was obtained. The biogas generation from inoculum was higher at $41^{\circ} \mathrm{C}$ than at stable conditions, and the acceleration in biogas production of the samples at $41^{\circ} \mathrm{C}$ can be explained with the temperature increase on day three, as presented in Figure 2.

In batch $B$, the difference was higher than in batch $A$. Approximately $70 \mathrm{Nml} / \mathrm{g}$ oDM biogas production difference was obtained from the samples at $36^{\circ} \mathrm{C}$ and $46^{\circ} \mathrm{C}$. Although higher biogas production was observed at $46^{\circ} \mathrm{C}$ for the inoculum samples, a $23 \mathrm{Nml} \mathrm{CH}_{4} / \mathrm{g}$ oDM higher biomethane was obtained from the pellets at $36^{\circ} \mathrm{C}$. Similar to batch $A$, acceleration in specific biogas production from pellets and from inoculum was observed on day three, as shown in Figure 3.

The $15^{\circ} \mathrm{C}$ temperature increase was studied in batch C. A quite different biogas generation graph was obtained from that last test compared to the first two. Retarded degradation was observed in inoculum samples at $51^{\circ} \mathrm{C}$ with approximately $200 \mathrm{Nml} / \mathrm{g}$ oDM higher biogas production than in inoculum samples at $36^{\circ} \mathrm{C}$ (see Figure 4). A $23 \mathrm{Nml}$ $\mathrm{CH}_{4} / \mathrm{g}$ oDM higher biomethane production than in the temperature-increased case was obtained at a stable temperature from pellets. As mentioned before, higher biogas formation can be observed at higher temperatures (Le Zhang, 2019) (Moset Veronica, 2015). The specific biogas production of inoculum sample after $15^{\circ} \mathrm{C}$ temperature increase was higher than other inoculum samples' productions. That can be explained with higher biogas production effi-

TABLE 2: DM and oDM content of substrates and inoculum.

\begin{tabular}{l|c:c} 
& DM [\%] & oDM [\%] \\
\hline Pellets & $89.3 \pm 0.14$ & $93.6 \pm 0.03$ \\
\hdashline Inoculum (used for $5^{\circ} \mathrm{C}$ increase batch) & $2.81 \pm 0.10$ & $62.34 \pm 0.52$ \\
\hdashline Inoculum (used for $10^{\circ} \mathrm{C}$ increase batch) & $3.42 \pm 0.25$ & $64.38 \pm 0.08$ \\
\hdashline Inoculum (used for $15^{\circ} \mathrm{C}$ increase batch) & $3.13 \pm 0.02$ & $64.36 \pm 0.22$ \\
\hline Cellulose (reference sample's substrate) & 96.65 & 100.00 \\
\hline
\end{tabular}

ciencies at higher temperatures after a specific time period of acclimatization. An adaptation of the microorganisms after a $15^{\circ} \mathrm{C}$ temperature increase could be obtained within 15 days, as represented in Figure 4 . The $10^{\circ} \mathrm{C}$ temperature increase caused instability in reactors. Because a $46^{\circ} \mathrm{C}$ operation temperature neither supplies an optimum living environment for mesophilic, nor for thermophilic microorganisms.

There are two types of enzymes degrading substrate in the biogas production process: endoenzymes and exoenzymes. Endoenzymes are produced by all bacteria, but exoenzymes are just produced by specific bacteria. Furthermore, enzymes degrade only a specific substrate or group of substrates. Therefore, a high diversity of bacteria is needed to ensure the degradation of specific types of substrate (Gerardi M. H., 2003). The reaction rate of enzymatic reactions depends on the $\mathrm{pH}$ and the temperature of the reactor. If the temperature increases beyond the optimum temperature ranges, the reaction can stop due to the denaturation of enzymes (Caballero-Arzápalo, 2015). Most of the enzymes are stable in the mesophilic range up to $37^{\circ} \mathrm{C}$ and become unstable a few degrees beyond, between $40^{\circ} \mathrm{C}$ and $50^{\circ} \mathrm{C}$ (Bisswanger, 2008). Based on this study, the highest biomethane generations areobtained at $36^{\circ} \mathrm{C}$, due to the suitability for enzymes of that temperature in the reaction.

As presented in Figure 5, the specific bio methane production of pellets at all temperature scenarios varied between $364.15 \pm 11.84$ and $420.48 \pm 16.93 \mathrm{Nml} \mathrm{CH}_{4} / \mathrm{g}$ oDM. In each case, a higher biomethane production was obtained at a stable temperature as compared to a temperature-changed situation. A change in operation temperatures led to instability in the process in each batch and caused lower specific biomethane production after temperature increases, as shown in Figure 5. The highest standard deviation was observed after $10^{\circ} \mathrm{C}$ temperature increase, which can be explained with the adaption challenges of microorganisms to the temperature between mesophilic and thermophilic temperature ranges. The highest difference between the methane contents of stable and un- 


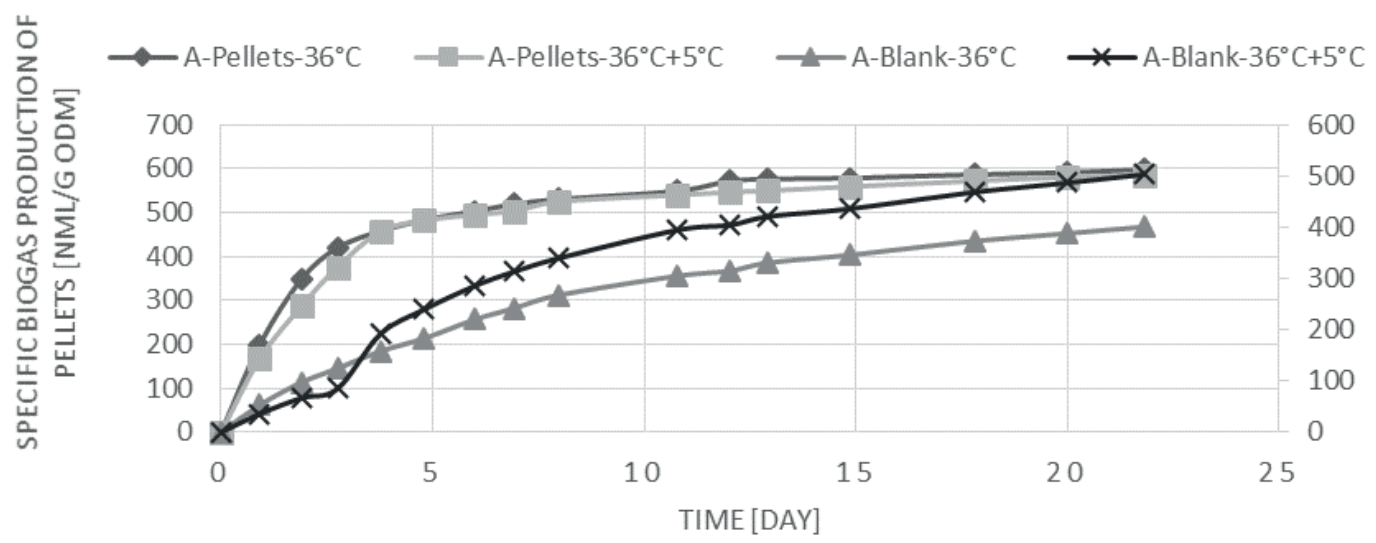

FIGURE 2: Specific fermentation gas production $-5^{\circ} \mathrm{C}$ increase.
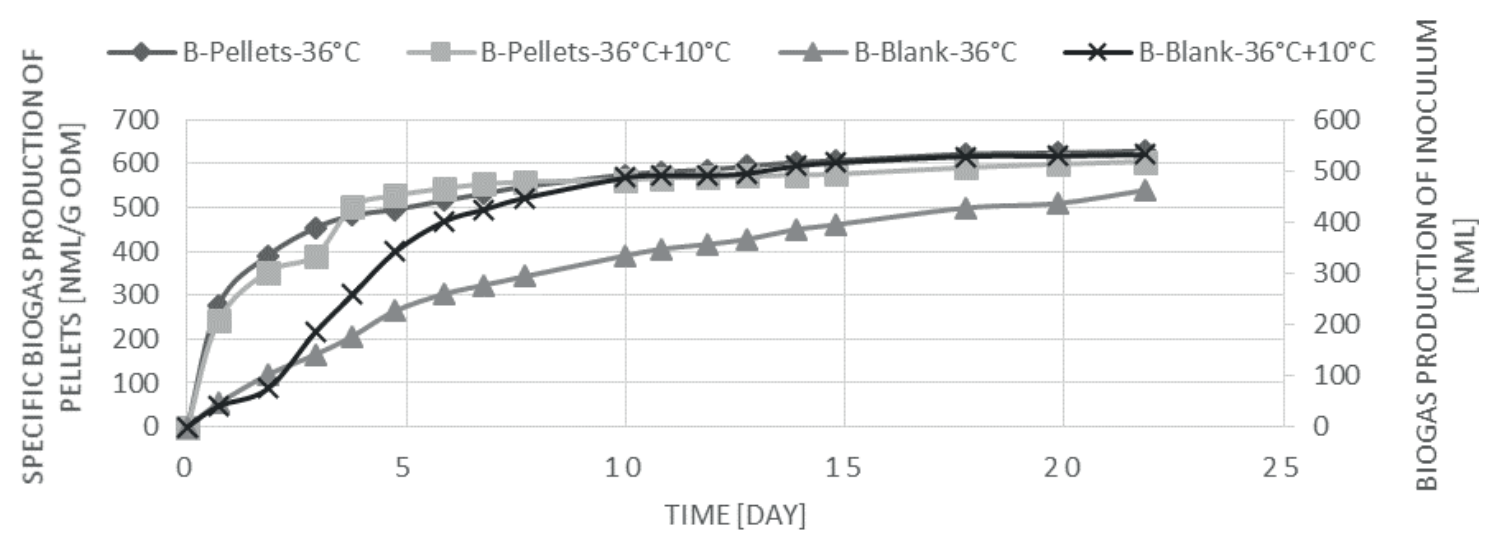

FIGURE 3: Specific fermentation gas production $-10^{\circ} \mathrm{C}$ increase.
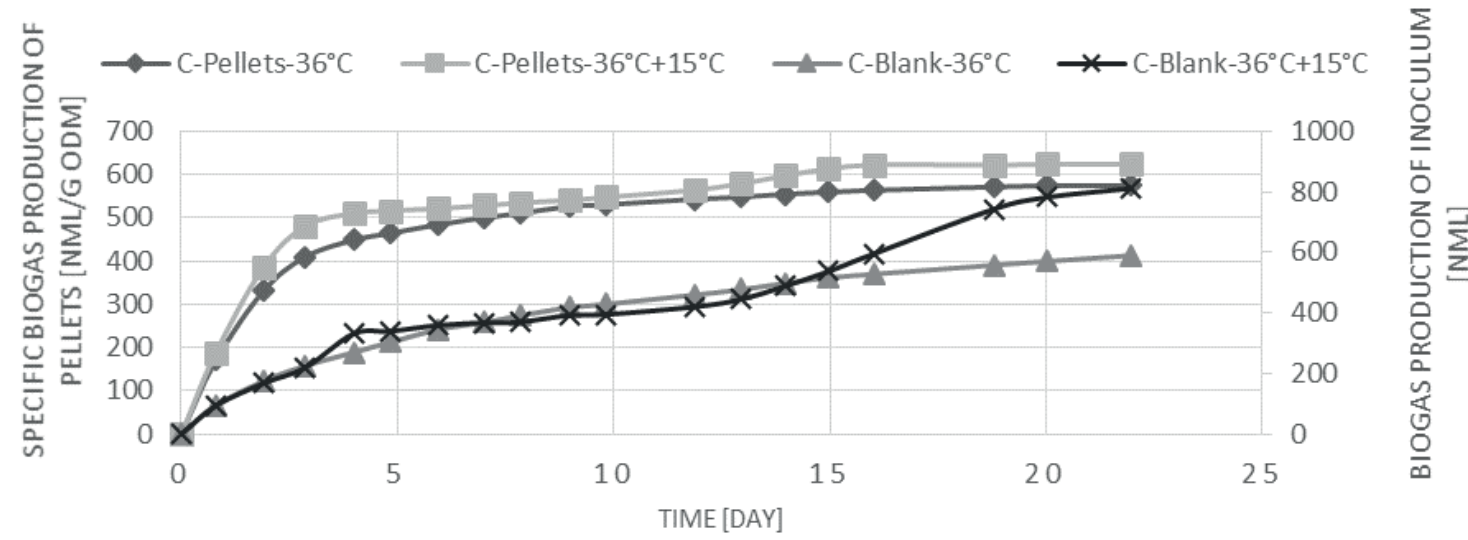

FIGURE 4: Specific fermentation gas production $-15^{\circ} \mathrm{C}$ increase.

stable temperature conditions was observed after a $15^{\circ} \mathrm{C}$ temperature increase, as depicted in Figure 6, which shows adaption problems of the process after an abrupt temperature change.

\subsection{Results of pH Measurements}

As mentioned in materials and methods part, the $\mathrm{pH}$ of each reactor was measured before and after the test. The results are presented in Table 3 . Before starting the experiment, slightly different $\mathrm{pH}$ values between the same samples was observed. Those differences were caused by impurities in inoculum sample. In each batch, higher $\mathrm{pH}$ values were obtained at higher temperatures as compared to stable conditions $\left(36^{\circ} \mathrm{C}\right)$. The concentration of ammonia strongly depends on the process temperature, hence increasing the temperature and temperature fluctuations led to an increase of ammonia concentration (Al Seadi, Rutz, \& Prassl, 2008) (FNR, Biogas, 2013). Therefore, it can cause $\mathrm{pH}$ increases, which were analysed at increased temperatures in the samples. Furthermore, hydrolysis and 

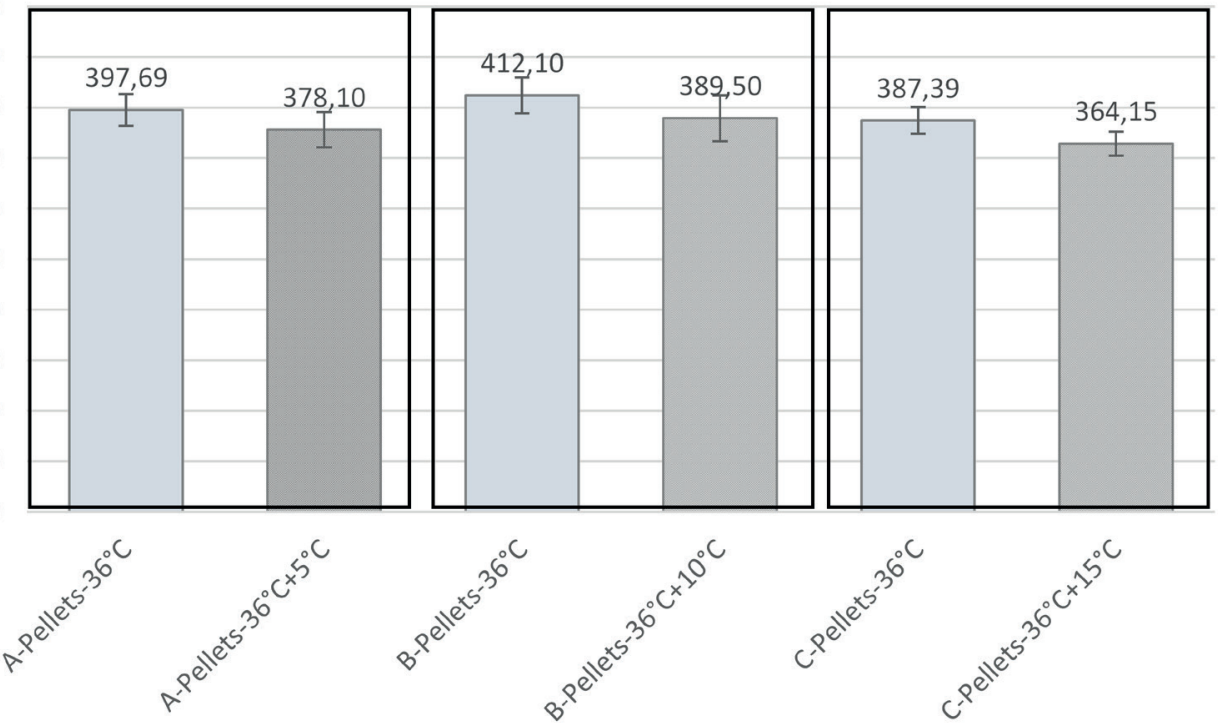

FIGURE 5: Specific bio-methane production of samples.
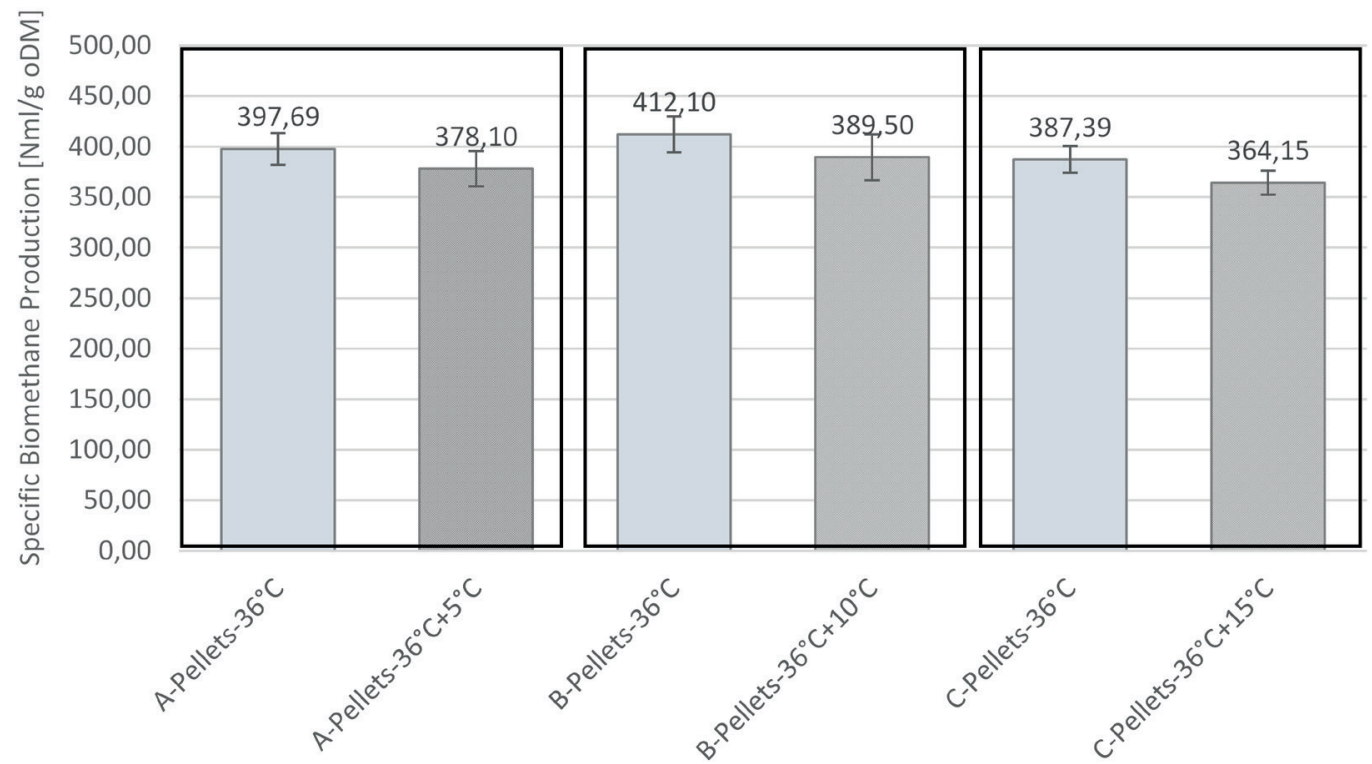

FIGURE 6: Methane content of biogas.

acidogenesis were negatively affected by higher temperatures due to the increasing concentration of ammonia (El-Mashad Hamed M., 2004). Overall, the pH and methane content of batch $\mathrm{C}$ showed that the process could not be adapted to temperature change successfully.

Considering all the results obtained from both pure inoculum and substrate analyses, the adaption of the pure inoculum samples to new operation temperatures was easier than mixed inoculum-feedstock samples. That can be caused by adaption challenges of enzymes that facilitate the degradation of the substrate within the whole process (Gerardi M. H., 2003). The results showed that without the inhibition of the process, the adaption to new conditions could be possible after $5^{\circ} \mathrm{C}$ temperature increases with a lower biomethane generation than in stable condi- tions. In the anaerobic digestion process, methanogens are the most sensitive group to temperature changes and other disturbances. Moreover, it is necessary to supply a balance between acetogens and methanogens in order to obtain stable biogas formation (Teimour Amani, 2010) (Gerber, 2009) (Caballero-Arzápalo, 2015). After $10^{\circ} \mathrm{C}$ and $15^{\circ} \mathrm{C}$ temperature increases, methanogens are affected negatively by changing the environment. Due to the high standard deviation of the methane content after a $10^{\circ} \mathrm{C}$ temperature increase, a detailed study is needed to get a clearer idea about the effect of operation at $46^{\circ} \mathrm{C}$. Varying results were observed after a $15^{\circ} \mathrm{C}$ increase for pure inoculum and inoculum-substrate mixture samples. On the one hand, an adaption of the inoculum sample at thermophilic conditions can be possible after a specific time of acclima- 
TABLE 3: $\mathrm{pH}$ values before and after the test.

\begin{tabular}{|c|c|c|c|}
\hline & Sample & pH- beginning & $\mathrm{pH}$ - end \\
\hline \multirow{4}{*}{$1^{\text {st }}$ set } & Blank- $36^{\circ} \mathrm{C}$ & $7.59 \pm 0.009$ & $7.60 \pm 0.017$ \\
\hline & Blank- $36^{\circ} \mathrm{C}+5^{\circ} \mathrm{C}$ & & $7.70 \pm 0.053$ \\
\hline & Pellets $-36^{\circ} \mathrm{C}$ & $7.50 \pm 0.024$ & $7.46 \pm 0.012$ \\
\hline & Pellets- $36^{\circ} \mathrm{C}+5^{\circ} \mathrm{C}$ & & $7.57 \pm 0.016$ \\
\hline \multirow{4}{*}{$2^{\text {nd }}$ set } & Blank-36 ${ }^{\circ} \mathrm{C}$ & $7.59 \pm 0.026$ & $7.60 \pm 0.020$ \\
\hline & Blank- $36^{\circ} \mathrm{C}+10^{\circ} \mathrm{C}$ & & $7.72 \pm 0.081$ \\
\hline & Pellets- $36^{\circ} \mathrm{C}$ & $7.51 \pm 0.021$ & $7.51 \pm 0.017$ \\
\hline & Pellets $-36^{\circ} \mathrm{C}+10^{\circ} \mathrm{C}$ & & $7.68 \pm 0.084$ \\
\hline \multirow{4}{*}{$3^{\text {rd }}$ set } & Blank- $36^{\circ} \mathrm{C}$ & $7.63 \pm 0.011$ & $7.64 \pm 0.119$ \\
\hline & Blank- $36^{\circ} \mathrm{C}+15^{\circ} \mathrm{C}$ & & $7.81 \pm 0.219$ \\
\hline & Pellets- $36^{\circ} \mathrm{C}$ & $7.54 \pm 0.017$ & $7.57 \pm 0.033$ \\
\hline & Pellets $-36^{\circ} \mathrm{C}+15^{\circ} \mathrm{C}$ & & $7.91 \pm 0.058$ \\
\hline
\end{tabular}

tization, but on the other hand, the temperature increase has caused process inhibition in the inoculum-substrate mixture samples. In further studies, the effect of temperature changes should be analysed with detailed microbiological studies concerning both samples.

\section{CONCLUSIONS}

This study examined the effect of temperature changes on biogas formation efficiency at different temperature ranges. It was found that an adaptation of the process to the new conditions is possible after $5^{\circ} \mathrm{C}$ and $10^{\circ} \mathrm{C}$ increases. Similar (higher than 64\%) methane content was observed in biogas from all reactors in the first two batches $A$ and B. However, the highest standard deviation was obtained after a $10^{\circ} \mathrm{C}$ increase. . After a $15^{\circ} \mathrm{C}$ increase, methane content was lower than in stable conditions and in the other batches, as well. Not only a decrease in methane content, but also high increases in the $\mathrm{pH}$ values were recorded in batch $\mathrm{C}$, caused by the adaptation problem of the process. Specific biomethane production amounts fluctuated in the range of $364-420 \mathrm{Nml} \mathrm{CH}_{4} / \mathrm{g}$ oDM, with the highest $10 \%$ dissimilarity. The specific biogas formation graphs showed that similar biogas generation could be obtained despite the destruction of the process by temperature changes, except in the case of a $15^{\circ} \mathrm{C}$ temperature increase as in batch C. After each temperature change, $\mathrm{pH}$ value increases were observed, but did not exceed 8 and stayed in the optimum range 7 and 8 . According to $\mathrm{pH}$ values obtained after the test, there was no inhibition observed in the test reactors. Hence our results indicate that the temperature fluctuations can be adapted by the process. Further research is needed to get detailed information about a $15{ }^{\circ} \mathrm{C}$ increase at the reactor temperature.

\section{ACKNOWLEDGEMENTS}

We are immensely grateful to the students and staff from the Institute of Environmental Technology and Energy Economics for their support. Special thanks to the German Academic Exchange Service (DAAD) for their scholarship for the researcher.

\section{REFERENCES}

Al Seadi, T., Rutz, D., \& Prassl, H. (2008). Biogas handbook.

Bisswanger, H. (2008). Enzyme Kinetics: Principles and Methods. Wiley-VCH Verlag $\mathrm{GmbH} \& \mathrm{Co}$. KGaA

Caballero-Arzápalo, N. (2015, September 10). Untersuchungen zum anaeroben Abbauprozess ausgewählter Abfallsubstrate mit Hilfe spezieller Mikroorganismen und Enzyme. Münich.

Demirel Burak, S. P. (2008). The roles of acetotrophic and hydrogenotrophic methanogens during anaerobic conversion of biomass to biomethane. Reviews in Environmental Science and Biotechnology, 173-190.

DIN. (n.d.). German standard methods for the examination of water, waste water and sludge - Parameters characterizing effects and substances (group H) - Part 7: Determination of acid and base-neutralizing capacities (H 7) , 2005.

DIN. (1983). German standard methods for the examination of water, waste water and sludge; cations (group E); determination of ammonia-nitrogen (E 5) .

DIN. $(1985,11)$. German standard methods for the examination of water, waste water and sludge; sludge and sediments (group S); determination of water content, of dry residue and of solids content (S 2).

DIN. (1987). Deutsche Einheitsverfahren zur Wasser-, Abwasser- und Schlammuntersuchung; Summarische Wirkungs- und Stoffkenngrößen (Gruppe H); Bestimmung des Gesamttrockenrückstandes, des Filtrattrockenrückstandes und des Glührückstandes $(\mathrm{H} 1)$.

DIN. (2001). Bestimmung des Glühverlustes der Trocknenmasse, DIN EN 12879 (S 3a) 2001-02, 2001.

DIN. (2001). Bestimmung des Trockenrückstandes und des Wassergehalts, DIN EN 12880 (S 2a) 2001-2,2001.

DIN. (2019). Water analysis - Guidelines for the determination of total organic carbon (TOC) and dissolved organic carbon (DOC); German version EN 1484:1997.

Dominika Kufka, M. B. (2019). Stable isotopes of C and H in methane fermentation of agriculture substrates at different temperature conditions. Open Geoscinces.

Drosg, B. (2013). Process monitoring in biogas plants. IEA Bioenergy .

El-Mashad Hamed M., Z. G. (2004). Effect of temperature and temperature fluctuation on thermophilic anaerobic digestion of cattle manure. Bioresource technology, 191-201.

FNR. (2010). Guide to Biogas: From production to use. Rostock: FNR, Abt. Öffentlichkeitsarbeit.

FNR. (2013). Biogas. Fachagentur Nachwachsende Rohstoffe e.V. (FNR).

Gerardi, M. H. (2003). The Microbiology of Anaerobic Digestion. Wiley-Interscience.

Gerber, M. (2009). Ganzheitliche stoffliche und energetische Modellierung des Biogasbildungsprozesses. Bochum.

Iranpour R., C. H. (2002). Changing Mesophilic Wastewater Sludge Digestion into Thermophilic Operation at Terminal Island Treatment Plant. Water and Environment Research, 497-507.

ISO. (2002). Water quality - Determination of the chemical oxygen demand index (ST-COD) - Small-scale sealed-tube method.

J.B. Holm-Nielsen, T. A.-P. (2009). The future of anaerobic digestion and biogas utilization. Bioresource Technology, pp. 5478-5484.

Jabłoński, S., Rodowicz, P., \& Łukaszewicz, M. (2015). Methanogenic archaea database containing physiological and biochemical characteristics. International journal of systematic and evolutionary microbiology , 1360-1368.

K. Kundu, I. B. (2014, January 30). Impact of abrupt temperature increase on the performance of an anaerobic hybrid bioreactor and its intrinsic microbial community. Bioresource Technology, pp. 7279.

Kayode Feyisetan Adekunle, J. O. (2015). A Review of Biochemical Process of Anaerobic Digestion. Advances in Bioscience and Biotechnology, 205-212.

Le Zhang, K.-C. L.-H. (2019, September ). Mesophilic and thermophilic anaerobic digestion of soybean curd residue for methane production: Characterizing bacterial and methanogen communities and their correlations with organic loading rate and operating temperature. Bioresource Technology.

Liangwei Deng, H. Y. (2014, August 7). Kinetics of temperature effects and its significance to the heatingstrategy for anaerobic digestion of swine wastewater. Applied Energy, pp. 349-355. 
Matteo Bavutti, L. G. (2014). Thermal stabilization of digesters of biogas plants by means of optimization of the surface radiative properties of the gasometer domes. 68th Conference of the Italian Thermal Machines Engineering Association, (pp. 1344-1353).

Methodenbuch, D. V. (n.d.). Bestimmung von Gesamt-Stickstoff nach KJELDAHL.

Moset Veronica, P. M. (2015). Mesophilic versus thermophilic anaerobic digestion of cattle manure: methane productivity and microbial ecology. Microbial biotechnology.

Protigrain, C. A. (2019, May 13). Retrieved from http://www.cropenergies.com/de/Lebens-Futtermittel/ProtiGrain/Qualitaet/ProtiGrain2011-DE_1.pdf

Rafaela Franqueto, J. D. (2019). Effect of Temperature Variation on Codigestion of Animal Waste and Agricultural Residue for Biogas Production. BioEnergy Research.
Streitwieser, D. A. (2017). Comparison of the anaerobic digestion at the mesophilic and thermophilic temperature regime of organic wastes from the agribusiness. Bioresource Technology, 985-992.

Suryawanshi, P. C., Chaudhari, A. B., \& Kothari, R. M. (2010). Thermophilic anaerobic digestion. The best option for waste treatment. Critical reviews in biotechnology, 31-40.

Teimour Amani, M. N. (2010). Anaerobic digestion from the viewpoint of microbiological, chemical, and operational aspects - A review. Environmental Reviews .

VDI. (2014). Vergärung organischer Stoffe Substratcharakterisierung, Probenahme, Stoffdatenerhebung, Gärversuche, VDI 4630.

Wu Man-chang, S. K. (2006). Influence of temperature fluctuation on thermophilic anaerobic digestion of municipal organic solid waste. . Journal of Zhejiang University, 180-185.

Ye Chen, J. J. (2007). Inhibition of anaerobic digestion process: A review. Bioresource Technology, pp. 4044-4064. 